\title{
Antioxidant Macromolecules in the Epithelial Lining Fluid of the Normal Human Lower Respiratory Tract
}

André M. Cantin, Gerald A. Fells, Richard C. Hubbard, and Ronald G. Crystal

Pulmonary Branch, National Heart, Lung, and Blood Institute, National Institutes of Health, Bethesda, Maryland 20892

\begin{abstract}
We hypothesized that the alveolar structures may contain extracellular macromolecules with antioxidant properties to defend against oxidants. To evaluate this ${ }^{51} \mathrm{Cr}$-labeled human lung fibroblasts (HFL-1) and cat lung epithelial cells (AKD) were exposed to a $\mathrm{H}_{2} \mathrm{O}_{2}$-generating system and alveolar epithelial lining fluid (ELF) from healthy nonsmokers was tested for its ability to protect the lung cells from $\mathrm{H}_{2} \mathrm{O}_{2}$-mediated injury. The ELF provided marked antioxidant protection, with most from a $\mathrm{H}_{2} \mathrm{O}$-soluble fraction in the $100-300-\mathrm{kD}$ range. Plasma proteins with anti- $\mathrm{H}_{2} \mathrm{O}_{2}$ properties were in insufficient concentrations to provide the antioxidant protection observed. However, catalase, a normal intracellular antioxidant, was present in sufficient concentration to account for most of the observed anti- $\mathrm{H}_{2} \mathrm{O}_{2}$ properties of ELF. Depletion of ELF with an anticatalase antibody abolished the anti- $\mathrm{H}_{2} \mathrm{O}_{2}$ macromolecular defenses of ELF. Since catalase is not normally released by cells, a likely explanation for its presence in high concentrations in normal ELF is that it is released by lung inflammatory and parenchymal cells onto the epithelial surface of the lower respiratory tract during their normal turnover and collects there due to the slow turnover of ELF. It is likely that catalase in the ELF of normal individuals plays a role in protecting lung parenchymal cells against oxidants present in the extracellular milieu. (J. Clin. Invest. 1990. 86:962-971.) Key words: catalase $\cdot$ hydrogen peroxide $•$ lung $\bullet$ inflammation • oxidants
\end{abstract}

\section{Introduction}

The alveoli of the lower respiratory tract provide the functional interface between the atmosphere and the body, allowing the exchange of oxygen and carbon dioxide between air and blood (1). As a consequence of this role, the cells composing the alveolar walls are placed under a burden of toxic oxygen radicals that is commonly greater than that of any other tissue $(2,3)$. In addition to the oxidants generated within the cells themselves (4), lung parenchymal cells are necessarily exposed to oxidant pollutants of the air, including oxides of nitrogen, ozone, and the gaseous phase of cigarette smoke (5, 6). Furthermore, the lower respiratory tract contains alveolar macrophages, cells that phagocytose inhaled particulates such as inorganic dusts, infectious organisms and particulates in

Address reprint requests to Dr. Ronald G. Crystal, Building 10, Room 6D03, National Heart, Lung, and Blood Institute, Bethesda, MD 20892.

Received for publication 2 September 1986 and in revised form 12 February 1990.

The Journal of Clinical Investigation, Inc.

Volume 86, September 1990, 962-971 cigarette smoke, but in doing so release toxic oxidants into their environment (7). Finally, many acute and chronic lung disorders are associated with inflammatory processes in the lower respiratory tract characterized by marked accumulation of activated inflammatory cells releasing oxidants $(8-11)$.

Like cells in other organs, the parenchymal cells of the lower respiratory tract are able to suppress the intracellular burden of oxidants with an array of intracellular antioxidants that include the superoxide dismutases (12), catalase (13), and the glutathione system (14). However, because of the unique situation of the alveolar structures with their potential exposures to a large oxidant burden in the extracellular milieu, we have considered the possibility that there may also be antioxidant defense mechanisms that would serve as a first line of defense against oxidants outside of the parenchymal cells.

To evaluate this concept, we tested the epithelial lining fluid (ELF) ${ }^{1}$ of the human lower respiratory tract for its ability to provide antioxidant protection to lung parenchymal cells from oxidants formed outside of the cells. To accomplish this, we have used a model system in which epithelial lining fluid was evaluated in vitro for the presence of macromolecules that might protect human lung fibroblasts or cat lung epithelial cells from a burden of hydrogen peroxide, an oxidant that plays a central role in the generation of a variety of oxidants to which lung parenchymal cells are potentially exposed.

\section{Methods}

\section{Overall design}

If an antioxidant system is to be broadly effective, it must be capable of suppressing hydrogen peroxide $\left(\mathrm{H}_{2} \mathrm{O}_{2}\right)$, an oxidant that itself is toxic and which plays a central role in the formation of the even more toxic oxidants, hydroxyl radical and hypochloride anion $(7,15-21)$. Thus, to evaluate epithelial lining fluid for the presence of macromolecules that may provide an antioxidant defense to the epithelial surface of the lower respiratory tract, we concentrated on a model in which epithelial lining fluid was tested for its ability to prevent injury to lung fibroblasts exposed to an oxidant-generating system that primarily generates $\mathrm{H}_{2} \mathrm{O}_{2}$.

\section{Cytotoxicity assay}

The target cells used were the normal human diploid fetal lung fibroblast strain, HFL-1 (CCL 153; American Type Culture Collection, Rockville, MD), previously frozen at passage 3-4 (22) and the cat diploid lung epithelial cell, AKD (CCL 151; ATCC), previously frozen at passage $20(23)$. Fibroblasts and epithelial cells were seeded at a density of 50,000 cells/well in 24-well culture plates (Falcon Labware, Cockeysville, MD) in $0.5 \mathrm{ml}$ DME (Gibco Laboratories, Grand Island, NY) supplemented with $10 \%$ calf serum (Biofluids, Inc., Rockville, $\mathrm{MD}$ ). The cells were grown to confluence in an atmosphere of $10 \%$ $\mathrm{CO}_{2}$ at $37^{\circ} \mathrm{C}$. At confluence, the cells were labeled with sodium chromate $\left({ }^{51} \mathrm{Cr}, 22 \mathrm{mCi} / \mathrm{nmol}, 5 \mu \mathrm{Ci} /\right.$ well; Amersham Chemical Co., Arlington Heights, IL) in DME-10\% calf serum for $12 \mathrm{~h}$ and the cells

1. Abbreviations used in this paper: $\mathrm{CI}$, cytotoxicity index; ELF, epithelial lining fluid. 
were then washed three times with PBS (M.A. Bioproducts, Walkersville, MD).

The cytotoxicity assay was performed by incubating the ${ }^{51} \mathrm{Cr}$-labeled lung cells in "assay media" that included $0.5 \mathrm{ml}$ of Earle's balanced salt solution (EBSS; ${ }^{1}$ Biofluids Inc., Rockville, MD) supplemented with $55 \mathrm{mM}$ glucose. To this was added $0.1 \mathrm{ml}$ of either PBS or epithelial lining fluid (see below). Oxidant production was initiated by adding $50 \mu \mathrm{l}$ of a glucose oxidase solution at varying concentrations (Boehringer-Mannheim Biochemicals, Indianapolis, IN) and the cells were incubated in $5 \% \mathrm{CO}_{2}$ at $37^{\circ} \mathrm{C}$ for $8 \mathrm{~h}$. Protease contamination of glucose oxidase was minimal (65 $\mathrm{U}$ glucose oxidase increased the optical density of $1 \mathrm{ml} 0.5 \%$ azocasein at $520 \mathrm{~mm}$ by 0.01 absorbance units after $1 \mathrm{~h}$ at $37^{\circ} \mathrm{C}$ ) as measured by the proteolytic assay described by Monboisse et al. (24). To ensure that ${ }^{51} \mathrm{Cr}$ release from target cells was induced by oxidants, the cells were also incubated in the presence of glucose plus glucose-oxidase and either $1 \mathrm{mM}$ growth-stimulating hormone, $4 \mathrm{mM}$ cysteine, $80 \mathrm{mM}$ dimethylthiourea, $100 \mathrm{U} / \mathrm{ml}$ catalase, boiled catalase (boiled at $100^{\circ} \mathrm{C}$ for $15 \mathrm{~min}$ ) or $1 \mathrm{mg} / \mathrm{ml} \mathrm{SOD}$ (all reagents from Sigma Chemical Co. [St. Louis, MO]). Maximum releasable ${ }^{51} \mathrm{Cr}$ was assessed by incubating cells with $2 \%$ Triton-X 100 (Research Products International Inc., Elk Grove Village, IL) and background release was evaluated by incubating cells in the absence of glucose oxidase. At the end of the incubation period, ${ }^{51} \mathrm{Cr}$ release in the supernatant was quantitated. Cell injury was defined in terms of a cytotoxicity index $(C \mathrm{C}):[(A-B) /(C-B)] \times 100$, where $A=$ disintegrations per minute released into the media of the test sample, $B=$ disintegrations per minute released from control cells (i.e., background release) and $C=$ disintegrations per minute released from cells treated with $2 \%$ Triton-X 100 . To insure that the ${ }^{51} \mathrm{Cr}$ measured in the supernatants reflected ${ }^{51} \mathrm{Cr}$ release from cell injury and not cell detachment, supernatants were centrifuged at $500 \mathrm{~g}$ for $10 \mathrm{~min}$ and ${ }^{51} \mathrm{Cr}$ was quantitated. The amount of chromium detected in centrifuged supernatants was identical to that of noncentrifuged supernatants even in the presence of sufficient glucose oxidase to induce maximal cytotoxicity. Furthermore, the cytotoxicity indices obtained by measuring ${ }^{51} \mathrm{Cr}$ release correlated with those calculated from lactate dehydrogenase measurements in the supernatants $(r=0.983, P<0.001)$. All subsequent cytotoxicity indices were therefore calculated from ${ }^{51} \mathrm{Cr}$ quantitation of non-centrifuged supernatants. Using this index, maximum cell injury was $100 \%$ and an index of $0 \%$ indicated no release of chromium above the spontaneous "leak" during the culture period. Typical counts for $B$ were $\sim 1.7 \times 10^{4} \mathrm{dpm} / \mathrm{ml}$ for AKD cells and $2.0 \times 10^{4}$ for HFL- 1 cells, whereas typical counts for $C$ were $10^{5} \mathrm{dpm} / \mathrm{ml}$ for both cell types.

The oxidants generated in $1 \mathrm{~h}$ at $37^{\circ} \mathrm{C}$ by the glucose-glucose oxidase system were evaluated by incubating the assay media with increasing amounts of glucose oxidase $(0-10 \mathrm{mU} / \mathrm{ml})$. The amount of hydrogen peroxide was quantitated with $0.28 \mathrm{mM}$ phenol red and 8.5 $\mathrm{U} / \mathrm{ml}$ of horseradish peroxidase (type II; 200 purpurogallin units/mg; Sigma Chemical Co.) (25). After $1 \mathrm{~h}$, the reaction mixture was treated with $0.01 \mathrm{~N} \mathrm{NaOH}$ and assessed spectrophotometrically at $610 \mathrm{~nm}$. Superoxide production was assessed by adding $80 \mu \mathrm{M}$ ferricytochrome- $c$ (type III; Sigma Chemical Co.) and evaluating the mixture at $550 \mathrm{~nm}(25)$.

\section{Evaluation of the antioxidant properties of unfractionated ELF}

(ELF) was obtained by bronchoalveolar lavage of 16 healthy nonsmoking individuals using $520-\mathrm{ml}$ aliquots of sterile $0.9 \% \mathrm{NaCl}$ in each of three sites as previously described (26). All of these individuals were determined to be free of lung disease by history, physical examination, chest $\mathrm{x}$-ray, and lung function tests. The fluid was separated from the lung cells by centrifugation at $500 \mathrm{~g}$ for $5 \mathrm{~min}$. Because the ELF, as recovered by bronchoalveolar lavage, is diluted $\sim 100$-fold by the saline, it was necessary to concentrate the fluid before it was assessed for its antioxidant properties. To accomplish this, the fluid was concentrated 50-fold by pressure filtration on a YM-10 membrane (Amicon Co., Lexington, MA). Thus, the antioxidants assessed were only those retained by the filter, i.e., $M_{\mathrm{r}} \sim>10 \mathrm{kD}$. Increasing amounts of the concentrated ELF were added to the cytotoxicity assay (before the addition of the glucose-oxidase), and the \% cytotoxicity determined at $8 \mathrm{~h}, 37^{\circ} \mathrm{C}$.

The actual amount of ELF added to each assay was determined by combining the measurement of the volume of ELF recovered by lavage and the ratio of the albumin in the concentrated fluid to the albumin in the unconcentrated fluid. The amount of ELF recovered by lavage was determined by the urea method (27). To relate all antioxidant activities to that in vivo, the amount of albumin was quantified by radial immunodiffusion in concentrated fluid and enzyme-linked immunosorbent assay in the unconcentrated lavage fluid. The ratio of antioxidant activity to albumin in the concentrated fluid was then used to determine the antioxidant activity in a volume of ELF containing an equivalent amount of albumin. In this context, wherever amounts of ELF are stated in the text, this amount refers to the calculated amount of ELF added, i.e., the estimate of the actual volume of ELF present in the lower respiratory tract.

\section{Fractionation of antioxidant macromolecules in ELF}

The concentrated ELF was fractionated by two methods: $(a)$ separation into water- and lipid-soluble components by density gradient $(\mathrm{NaBr})$ centrifugation; and $(b)$ fractionation by molecular weight.

The water and lipid components of ELF were separated by layering $12 \mathrm{ml}$ of unconcentrated bronchoalveolar lavage fluid containing 1.56 $\mathrm{M} \mathrm{NaBr}$ (Sigma Chemical Co.) under $20 \mathrm{ml}$ of $0.15 \mathrm{M} \mathrm{NaCl}, 1.27 \mathrm{M}$ $\mathrm{NaBr}$, which was layered under $8 \mathrm{ml}$ of $0.15 \mathrm{M} \mathrm{NaCl}$ and centrifuged at $100,000 \mathrm{~g}$, at $4^{\circ} \mathrm{C}$ for $3 \mathrm{~h}$ (SW-27 rotor; Beckman Instruments, Inc., Fullerton, CA) (28). The lipid fraction was collected from the upper interface (density $=1.085$ ) and the water-soluble fraction was collected from the $12 \mathrm{ml}$ at the bottom of the gradient. The lipid fraction was washed three times in PBS and brought to a volume of $240 \mu$ in PBS. The soluble fraction was concentrated by pressure filtration on a YM-10 membrane to a volume of $240 \mu \mathrm{l}$ in PBS. Since sample preparation required a prolonged period of time during which ELF was exposed to air, it was necessary to add a reducing agent to each fraction to prevent sample oxidation. Each fraction was therefore subsequently treated with $20 \mathrm{mM} 2$-mercaptoethanol and dialyzed extensively against PBS for $12 \mathrm{~h}$. Control samples of buffer and 2-mercaptoethanol heated in the same way did not affect the cytotoxicity assays. After this, $80 \mu$ lof each fraction were tested in the cytotoxicity assay.

To fractionate the ELF by molecular weight, concentrated ELF was centrifuged at $12,000 \mathrm{~g}$ for $15 \mathrm{~min}$ and fractionated by HPLC (Beckman Instruments, Inc.) using a Superose 6 and Superose 12 column in series (Pharmacia Fine Chemicals, Piscataway, NJ) in $0.15 \mathrm{M} \mathrm{NaCl}$, $7.5 \mathrm{mM}$ sodium phosphate, $\mathrm{pH}$ 7.4. Fractions corresponding to various molecular weights were pooled, concentrated by ultrafiltration to the same volume as the original sample on Minicon-CS 15 membranes (Amicon Co.) and tested for their antioxidant properties in the cytotoxicity assay as described above.

\section{Evaluation of serum proteins in ELF that might serve as antioxidants}

Four serum proteins, albumin, IgG, ceruloplasmin, and $\alpha 1$-antitrypsin, all known to be present in ELF (29), were each evaluated for their antioxidant properties in the cytotoxicity assay. ELF and serum concentrations of each of these proteins were determined by radial immunodiffusion assay (Calbiochem-Behring Corp., La Jolla, CA). The concentrations present in ELF were used to determine the range of values to be assessed in the cytotoxicity assay and the concentration required to provide a $50 \%$ reduction in the cytotoxicity index was determined.

\section{Identification of catalase as the major antioxidant macromolecule in $E L F$}

Together, preliminary fractionation data and the measurement of the relative contribution to ELF antioxidants by serum proteins suggested that: (a) the majority of the antioxidant protection offered by ELF was not due to serum proteins with known antioxidant properties; $(b)$ the 
antioxidant(s) were water soluble; and (c) the antioxidant(s) had a molecular mass range of $100-300 \mathrm{kD}$. With this information as a background, we hypothesized that the antioxidant properties of ELF may be derived from the release of intracellular antioxidants by parenchymal and/or inflammatory cells present in the local milieu of the lower respiratory tract and began a search for antioxidant molecules in ELF that might be derived from known intracellular antioxidants. Among the antioxidant proteins synthesized by lung cells, only catalase has a molecular mass $(240 \mathrm{kD})$ within the range in which the ELF anti- $\mathrm{H}_{2} \mathrm{O}_{2}$ properties were identified.

In this context, ELF catalase activity was quantified by using a modification of the method described by Aebi (30) in which $450 \mu \mathrm{l}$ of $10 \mathrm{mM} \mathrm{H}_{2} \mathrm{O}_{2}$ (Mallinkrodt Inc., Paris, $\mathrm{KY}$ ) in $0.15 \mathrm{M} \mathrm{NaCl}, 7.5 \mathrm{mM}$ sodium phosphate, $\mathrm{pH} 7.4$, were reacted with $50 \mu \mathrm{l}$ ELF. The initial (0-30 s) rate of disappearance of $\mathrm{H}_{2} \mathrm{O}_{2}$ was recorded spectrophotometrically at a wavelength of $240 \mathrm{~nm} ; 1 \mathrm{U}$ of catalase activity was defined as the rate constant of the first order reaction (30). To accomplish this, catalase was purified from human red blood cells according to methods described by Bonaventura et al. (31), and antibodies to catalase were raised in sheep and coupled to cyanogen bromide-activated Sepharose 4-B beads (Pharmacia Fine Chemicals) equilibrated in $0.15 \mathrm{M} \mathrm{NaCl}$, $7.5 \mathrm{mM}$ phosphate, $\mathrm{pH}$ 7.4. The purity of the catalase antigen was assessed by $7.5 \%$ PAGE and the specificity of the anticatalase antiserum was determined by immunodiffusion analysis in agar. ELF was tested for its antioxidant properties before and after it was passed through the anticatalase column by incubating $100 \mu \mathrm{l} \mathrm{ELF}$ (containing $0.2 \mathrm{mg}$ albumin as a carrier to maintain similar amounts of protein in both incubations) with the labeled cells in the presence of the oxidantgenerating system at $37^{\circ} \mathrm{C}$ for $8 \mathrm{~h}$.

\section{Evaluation of the possible sources of ELF catalase}

Since catalase is predominantly an intracellular enzyme, it is likely that ELF catalase is derived from one of the multiple cell types present in the lower respiratory tract. Thus, the possible sources of ELF catalase include red blood cells, lung inflammatory cells, and lung parenchymal cells. To gain insight as to whether these cells contribute to the catalase present in ELF, the following experiments were performed.

Red blood cells. Although red blood cells are rarely found in bronchoalveolar lavage samples of normal individuals, to determine whether red blood cell lysis contributed to the presence of catalase in ELF, either as an in vivo process or as an artifact of the lavage procedure, concentration of hemoglobin in ELF was quantified by recording the absorbance of the Soret band at a wavelength of $414 \mathrm{~nm}$ (32). The ratio of catalase activity to hemoglobin content of ELF was compared with that of the red blood cell lysate supernatant.

Lung inflammatory cells. To exclude the possibility that the lavage procedure artifactually contributed to the ELF catalase by lysing lung inflammatory cells during the procedure itself, bronchoalveolar lavage fluid obtained from a healthy individual was separated in two aliquots. One aliquot was immediately centrifuged $(500 \mathrm{~g}, 5 \mathrm{~min})$ and the catalase content was determined in the supernatant. The second aliquot was aspirated through the bronchoscope in the laboratory using the same suction apparatus as in the in vivo procedure, the recovered fluid was immediately centrifuged $(500 \mathrm{~g}, 5 \mathrm{~min})$, and the catalase content of the ELF was determined.

If the catalase found in ELF was derived from cell types other than (or in addition to) inflammatory cells, the relative amounts of various cytoplasmic enzymes found in ELF should differ from that of the inflammatory cell populations present in the lower respiratory tract. To evaluate this, the amounts of the antioxidant enzymes catalase, SOD, glutathione peroxidase, and glutathione reductase were measured in ELF and in lung inflammatory cells and their relative proportions compared with that in ELF. ELF was prepared as described above, centrifuged at $12,000 \mathrm{~g}$ for $5 \mathrm{~min}$, and assays for enzyme activity were performed on the supernatant. Inflammatory cells recovered by lavage were washed three times with PBS and suspended in PBS $\left(10^{6} / \mathrm{ml}\right)$, sonicated (Sonifier; Ultrasonics Inc., Plainview, NY), centrifuged at $25,000 \mathrm{~g}$ for $15 \mathrm{~min}$, and antioxidant enzyme activity mea- sured in the supernatants. For both the ELF and the inflammatory cell lysates, catalase was measured as described above. SOD activity was measured by reacting sufficient xanthine oxidase with $50 \mu \mathrm{M}$ xanthine to cause an increase in absorbance of a $10 \mu \mathrm{M}$ ferricytochrome- $c$ solution of 0.02 absorbance units/min in $50 \mathrm{mM}$ phosphate buffer containing $0.1 \mathrm{mM}$ EDTA and $10 \mu \mathrm{M}$ potassium cyanide at $\mathrm{pH} 7.8(33) .1$ $\mathrm{U}$ of SOD was defined as the activity necessary to inhibit the increase in absorbance by $50 \%$. Glutathione peroxidase was measured spectrophotometrically at a wavelength of $340 \mathrm{~nm}$ in $50 \mathrm{mM}$ phosphate, 5 mM EDTA, pH 7.0, containing $0.3 \mathrm{mM}$ NADPH, $0.3 \mathrm{U} / \mathrm{ml}$ glutathione reductase, $5 \mathrm{mM}$ glutathione, $4 \mathrm{mM}$ sodium azide, $75 \mu \mathrm{M} \mathrm{H}_{2} \mathrm{O}_{2}$, and $100 \mu \mathrm{l}$ of sample in a final volume of $3 \mathrm{ml}$ (34). One unit of glutathione peroxidase activity was defined as the amount necessary to oxidize $1 \mu \mathrm{mol} \mathrm{NADPH} / \mathrm{min}$. Glutathione reductase activity was measured by recording spectrophotometrically the reduction of $100 \mu \mathrm{l}$ $150 \mu \mathrm{M}$ glutathione disulfide, in the presence of $1 \mathrm{ml} 144 \mu \mathrm{M}$ NADPH in $0.3 \mathrm{M}$ Tris- $\mathrm{HCl}, \mathrm{pH} 7.0$, and $0.5 \mathrm{ml}$ of sample (35); one unit of activity was defined as the amount of glutathione reductase necessary to reduce $1 \mu \mathrm{mol}$ glutathione disulfide/min. After these measurements, the relative amounts of each enzyme in ELF (milliunits/microliter) was compared with that in the inflammatory cells (milliunits $/ 10^{3}$ cells) i.e., if the ratios were the same for each enzyme, it would suggest that only the inflammatory cells contributed to the ELF enzymes, but if the ratios varied, it would suggest that sources other than the inflammatory cells also contributed.

Lung parenchymal cells. To indirectly evaluate the possibility that effects other than lung inflammatory cells (e.g., lung parenchymal cells) may contribute catalase present in ELF, the isoenzyme patterns of ELF catalase were compared with those of lung inflammatory cells obtained from the same individuals. To do this, lung inflammatory cell lysates and ELF were prepared as described above, and each sample was brought to a catalase concentration of $1 \mathrm{U} / \mathrm{ml}$ in $150 \mathrm{mM}$ saline. $40 \mu \mathrm{l}$ of each sample containing $40 \mathrm{mU}$ catalase or $40 \mu \mathrm{l}$ of a $1: 1$ mixture of ELF and inflammatory cell lysate containing $80 \mathrm{mU}$ catalase were loaded on a $5 \%$ polyacrylamide slab gel (without SDS) and electrophoresed at $60 \mathrm{~mA}$ for $4 \mathrm{~h}$. The gel was then washed in water (15 min each) and placed in $1 \mathrm{mM} \mathrm{H}_{2} \mathrm{O}_{2}$ for $10 \mathrm{~min}$. After a brief wash in water, the gel was stained in a solution containing $37 \mathrm{mM}$ ferric chloride, $30 \mathrm{mM}$ potassium ferricyanide (36) until areas of catalase activity were distinctly visible as clear bands against a green background.

\section{Statistical analysis}

All data are expressed as the mean $\pm \mathrm{SEM}$; all statistical comparisons are made using the two-tailed $t$ test.

\section{Results}

Oxidant-generating system and its effect on human lung parenchymal cells. The reaction of glucose with the enzyme glucose-oxidase resulted in the generation of hydrogen peroxide in the media but no detectable superoxide anion (Fig. 1). The amount of $\mathrm{H}_{2} \mathrm{O}_{2}$ generated by this reaction was dependent on the concentration of glucose-oxidase, and the release of $\mathrm{H}_{2} \mathrm{O}_{2}$ occurred over a gradual period of time, thus simulating the release of $\mathrm{H}_{2} \mathrm{O}_{2}$ from activated phagocytes. When the hydrogen peroxide generating system was incubated with labeled human lung fibroblasts or cat lung epithelial cells, a significant amount of ${ }^{51} \mathrm{Cr}$ was released into the media. Glucose oxidase in the absence of glucose did not induce the release of ${ }^{51} \mathrm{Cr}$ from HFL-1 and AKD cells up to concentrations of $60 \mathrm{mU} / \mathrm{ml}$ (Fig. 1). Furthermore, the release of ${ }^{51} \mathrm{Cr}$ from HFL-1 cells was suppressed by $100 \mathrm{U} / \mathrm{ml}$ catalase (CI: from $78 \pm 2$ to $0 \pm 2 \%, P$ $<0.001), 1 \mathrm{mM}$ GSH (CI: from $18 \pm 3$ to $0 \pm 1 \%, P<0.01) 4$ $\mathrm{mM}$ cysteine (CI: from $24 \pm 1$ to $0 \pm 1 \%, P<0.01)$ but unchanged by $1 \mathrm{mg} / \mathrm{ml} \mathrm{SOD} \mathrm{(CI:} \mathrm{from} 78 \pm 2$ to $79 \pm 2 \%, P>0.5$ ). 

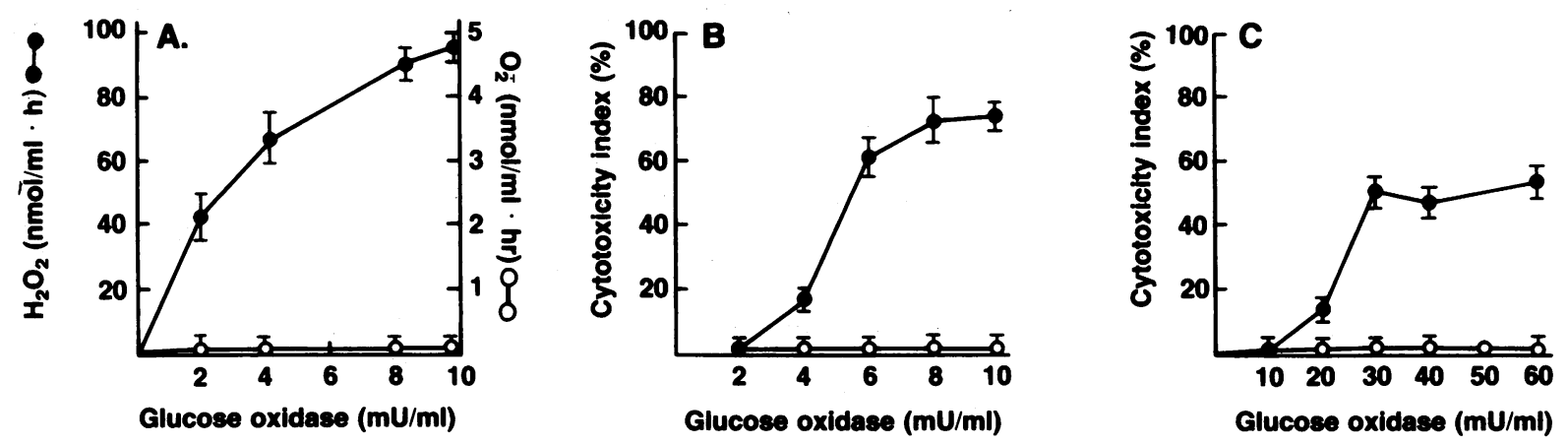

Figure 1. Cytotoxicity assay for assessing hydrogen peroxide-mediated injury to lung parenchymal cells. $(A)$ Oxidant-generating system used in the cytotoxicity assay. Glucose $(55 \mathrm{mM})$ was incubated with increasing amounts of glucose oxidase $\left(8 \mathrm{~h}, 37^{\circ} \mathrm{C}\right)$, and the amount of hydrogen peroxide $\left(\mathrm{H}_{2} \mathrm{O}_{2}\right)$ and superoxide anion $\left(\mathrm{O}_{2}^{\dot{)}}\right)$ generated were quantified using phenol red and ferricytochrome-c, respectively, as indicators. Only $\mathrm{H}_{2} \mathrm{O}_{2}$ is produced by this system. $(B)$ Cytotoxicity of human lung fibroblasts $(H L F-1)$ and $(C)$ cat lung epithelial cells $(A K D)$ caused by the glucose-glucose oxidase oxidant-generating system. ${ }^{51} \mathrm{Cr}$-labeled HFL-1 and AKD cells were incubated with $(\bullet)$ and without $(0)$ glucose $(55 \mathrm{mM})$ and increasing amounts of glucose oxidase for $8 \mathrm{~h}, 37^{\circ} \mathrm{C}$ and a cytotoxicity index determined. The relative amount of ${ }^{51} \mathrm{Cr}$ released paralleled that of the amount of $\mathrm{H}_{2} \mathrm{O}_{2}$ generated at each concentration of glucose oxidase.

${ }^{51} \mathrm{Cr}$ released from $\mathrm{AKD}$ cells was suppressed by $100 \mathrm{U} / \mathrm{ml}$ catalase (CI: from $20 \pm 2$ to $1 \pm 1 \%, P<0.05$ ), $1 \mathrm{mM} \mathrm{GSH} \mathrm{(CI:}$ from $13 \pm 2$ to $0 \pm 1 \%, P<0.01$ ) but unchanged by heat-inactivated catalase (CI: from $20 \pm 2$ to $21 \pm 3 \%, P>0.5$ ) and by 1 $\mathrm{mg} / \mathrm{ml} \mathrm{SOD} \mathrm{(CI:} \mathrm{from} 20 \pm 2$ to $21 \pm 2 \%, P>0.5$ ). Glucose-oxidase at a concentration of $8 \mathrm{mU} / \mathrm{ml}$ induced maximum release of ${ }^{51} \mathrm{Cr}$ from the HFL-1 cells; this concentration of glucose-oxidase generated $90 \mathrm{nmol} \mathrm{H}_{2} \mathrm{O}_{2} / \mathrm{h}$ per $\mathrm{ml}$ of media. Because the in vitro system was designed to evaluate the macromolecules in ELF that might provide antioxidant protection against a typical burden of $\mathrm{H}_{2} \mathrm{O}_{2}$ in the human lower respiratory tract, the amount of glucose oxidase used in all subsequent experiments was based on the estimated amount of $\mathrm{H}_{2} \mathrm{O}_{2}$ generated by inflammatory cells in the ELF of cigarette smokers (a typical example of a common human situation in which the lower respiratory tract must content with increased oxidant burden). Since $10^{6}$ alveolar macrophages from cigarette smokers release from 3 to $8 \mathrm{nmol}$ of $\mathrm{H}_{2} \mathrm{O}_{2} / \mathrm{h}$ in vitro (9) and since there are $\sim 15 \times 10^{6}$ macrophages per $\mathrm{ml}$ of ELF of cigarette smokers $(25,27)$, a reasonable estimate of the potential $\mathrm{H}_{2} \mathrm{O}_{2}$ burden in ELF of cigarette smokers is between 45 and $120 \mathrm{nmol} / \mathrm{ml}$ per h. For these reasons, a concentration of glucose-oxidase of 8 $\mathrm{mU} / \mathrm{ml}$ was chosen for all subsequent experiments with HFL-1 cells. Since AKD cells required higher levels of $\mathrm{H}_{2} \mathrm{O}_{2}$ to induce cytotoxicity, a concentration of glucose-oxidase of 30 $\mathrm{mU} / \mathrm{ml}$ was used in the experiments involving AKD cells.
Effect of normal epithelial lining fluid on the oxidant-mediated injury to human lung parenchymal cells. ELF from healthy nonsmoking individuals markedly reduced the $\mathrm{H}_{2} \mathrm{O}_{2}$ induced cytotoxicity of the target cells in a dose-dependent manner, with $20 \mu$ l of ELF reducing the HFL-1 cytotoxicity index from $65 \pm 4$ to $0 \pm 1 \%$ (Fig. $2, P<0.001$ compared with no ELF) and the AKD cell cytotoxicity index from $39 \pm 2$ to $8 \pm 4 \%$ (Fig. $2 B, n=8, P<0.01$ ). By itself, the ELF did not alter the spontaneous release of ${ }^{51} \mathrm{Cr}$ from the lung parenchymal cells in the absence of oxidants (data not shown).

Fractionation of antioxidant macromolecules in ELF. Centrifugation of ELF on a sodium bromide density gradient-separated it into a lipid-free, water-soluble fraction and a lipidenriched fraction. Whereas the lipid-enriched fraction caused only a slight reduction in the cytotoxicity index to $45 \pm 5 \%$ (Fig. $3, n=6, P<0.05$ compared with oxidants alone), the watersoluble fraction of ELF markedly reduced the cytotoxicity index to $0 \pm 1 \%$ ( $n=6, P<0.001$ compared with oxidants alone; $P<0.005$ compared to the lipid soluble fraction), suggesting that most of the anti- $\mathrm{H}_{2} \mathrm{O}_{2}$ activity of ELF was in the water-soluble fraction.

To further characterize the molecules in the water-soluble fraction that may contribute to the antioxidant properties of ELF, the ELF was fractionated by gel filtration, and fractions corresponding to various molecular weight ranges were tested in the cytotoxicity assay. All of the antioxidant activity eluted

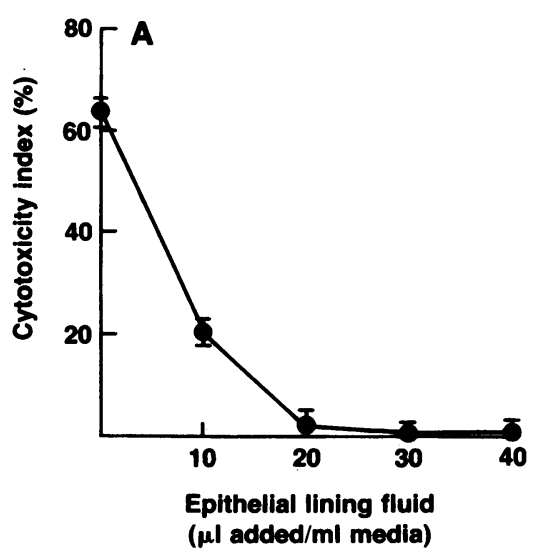

( $\mu$ l added/mi media)

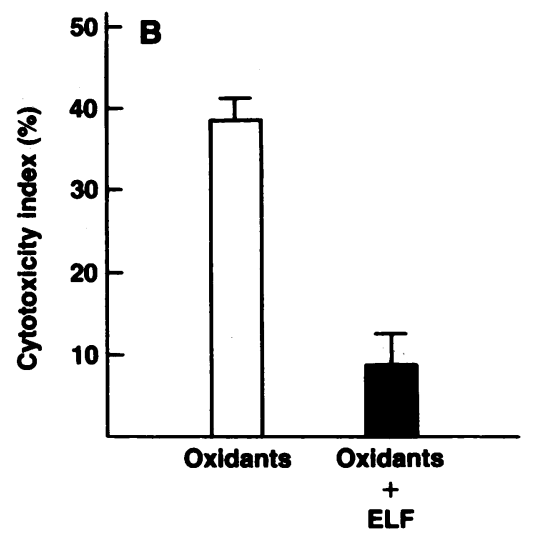

Figure 2. Evaluation of the ability of lower respiratory tract epithelial lining fluid $(E L F)$ to protect lung parenchymal cells against hydrogen peroxide-mediated injury. $(A){ }^{51} \mathrm{Cr}$-labeled HFL- 1 cells were incubated $\left(8 \mathrm{~h}, 37^{\circ} \mathrm{C}\right)$ with the $\mathrm{H}_{2} \mathrm{O}_{2}$-generating system ( $55 \mathrm{mM}$ glucose, $8 \mathrm{mU} / \mathrm{ml}$ glucose-oxidase) in the presence of varying amounts of ELF obtained from a normal, nonsmoking individual. $(B){ }^{51} \mathrm{Cr}$-labeled AKD cells were incubated $\left(8 \mathrm{~h}, 37^{\circ} \mathrm{C}\right)$ with the $\mathrm{H}_{2} \mathrm{O}_{2}$ generating system ( $55 \mathrm{mM}$ glucose, $30 \mathrm{mU} / \mathrm{ml}$ glucose-oxidase) in the presence of $25 \mu \mathrm{l}$ ELF obtained from eight normal nonsmoking individuals. 


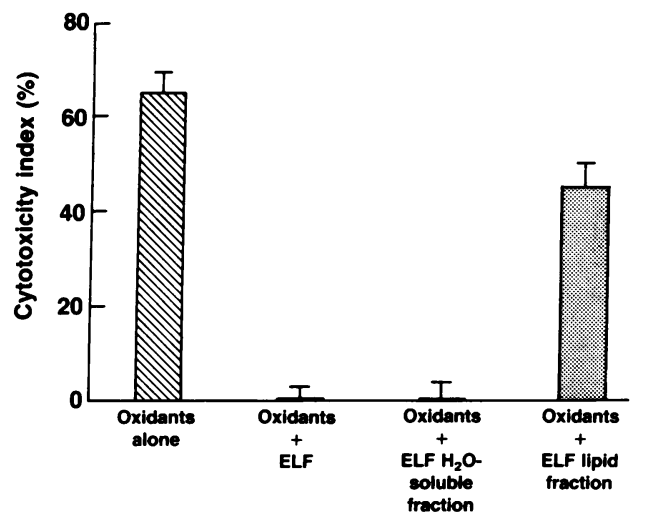

Figure 3. Comparison of the antioxidant properties of the water-soluble and lipid-enriched fractions of lower respiratory tract epithelial lining fluid $(E L F) .{ }^{51} \mathrm{Cr}$-labeled HFL-1 cells were incubated with the $\mathrm{H}_{2} \mathrm{O}_{2}$ generating system as described in the legend to Fig. 1. The water-soluble and lipid components of ELF were separated on a sodium bromide gradient, both fractions were dialyzed against PBS, and each fraction was then tested for its ability to protect HFL-1 cells against the $\mathrm{H}_{2} \mathrm{O}_{2}$ generated in the cytotoxicity assay. The amount of ELF placed on the sodium bromide gradient was $240 \mu \mathrm{l}$, and each of the water-soluble and lipid-enriched fractions was adjusted to a final volume of $240 \mu \mathrm{l}$. The amounts of whole ELF and water-soluble and lipid components used in the cytotoxicity assay were each $80 \mu \mathrm{l}$ per $500 \mu \mathrm{l}$ of test media.

in a single fraction corresponding to a molecular mass range of $100-30$ kD (Fig. 4). Furthermore, catalase activity was clearly detectable in this fraction but not in other fractions (Fig. $4 \mathrm{~A}$ ).

Antioxidant properties of serum-derived proteins in ELF. Since many of the water-soluble components of ELF are proteins derived from serum, the serum proteins likely to give anti- $\mathrm{H}_{2} \mathrm{O}_{2}$ protection, ceruloplasmin, and $\alpha 1$-antitrypsin, were examined as were two major serum proteins, albumin, and IgG not likely to provide anti- $\mathrm{H}_{2} \mathrm{O}_{2}$ protection (Table I). Although human albumin $(2 \mathrm{mg} / \mathrm{ml})$ and immunoglobulin $(2$ $\mathrm{mg} / \mathrm{ml}$ ) did not suppress the oxidant-mediated cytotoxicity in the in vitro test system, ceruloplasmin at a concentration of $215 \pm 40 \mu \mathrm{g} / \mathrm{ml}$ and $\alpha 1$-antitrypsin at a concentration of $450 \pm 100 \mu \mathrm{g} / \mathrm{ml}$ caused a $50 \%$ reduction in the cytotoxicity index ( $n=6, P<0.01$, both compared to oxidants alone). However, although the addition of $40 \mu$ l ELF to $1 \mathrm{ml}$ media completed protected the lung cells against oxidant injury, the concentration of ceruloplasmin $(0.8 \mu \mathrm{g} / \mathrm{ml})$ and $\alpha 1$-antitrypsin $(8 \mu \mathrm{g} / \mathrm{ml})$ in ELF were well below the levels necessary to provide significant antioxidant protection, suggesting that these serum proteins did not contribute to the anti- $\mathrm{H}_{2} \mathrm{O}_{2}$ protection observed in ELF.

Identification of catalase as the major ELF antioxidant macromolecule. Catalase activity (i.e., the ability to convert $\mathrm{H}_{2} \mathrm{O}_{2}$ to $\mathrm{H}_{2} \mathrm{O}$ plus $\mathrm{O}_{2}$ ) was clearly present in all samples of normal ELF (Fig. 5). Furthermore, specific immunoabsorption of catalase from the ELF resulted in a complete loss of catalase activity from ELF. The antibody used to deplete ELF of catalase was specific to catalase and did not react with other red blood cell or serum proteins (Fig. 5). Importantly, when catalase was immunoabsorbed from the ELF, the ELF no longer provided antioxidant protection to the lung parenchymal cells $(P<0.001)$. As a control for this observation, ELF chromatographed on Sepharose 4-8 columns coupled to either
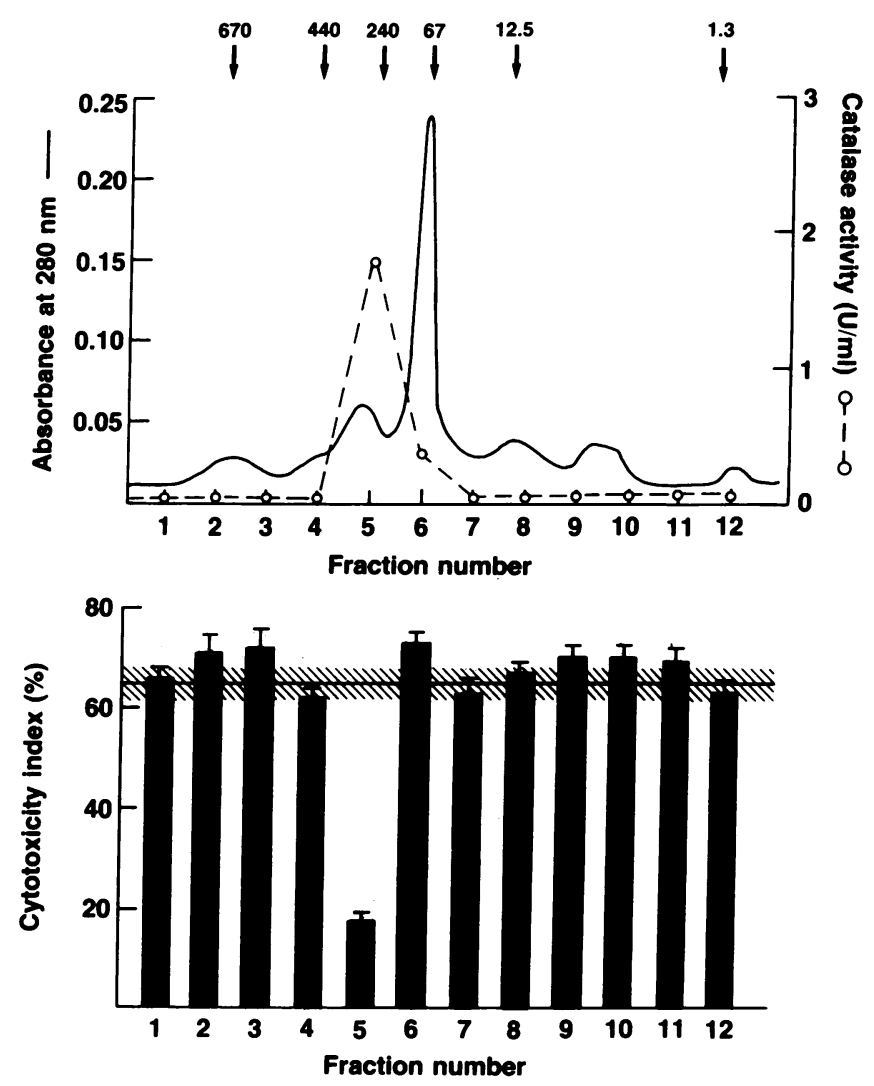

Figure 4. Characterization of the antioxidant activity of ELF by gel filtration. ELF obtained from healthy nonsmokers was chromatographed by HPLC on Superose 6 and 12 columns in series in 150 $\mathrm{mM} \mathrm{NaCl}, 7.5 \mathrm{mM} \mathrm{NaPO}_{4}, \mathrm{pH}$ 7.4. (Top) The eluate was monitored for absorbance at $280 \mathrm{~nm}$ (solid line) and for catalase activity (O); and (Bottom) the antioxidant activity of various pooled fractions was tested in the cytotoxicity assay described in the legend to Fig. 1. Whereas oxidants alone induced a cytotoxicity index of $64 \pm 3 \%$, the pooled fraction eluting within the molecular weight range of 100,000 to 300,000 significantly reduced the cytotoxicity index.

antihuman ceruloplasmin antibodies or protein A (Pharmacia Fine Chemicals) did not result in a loss of ELF antioxidant properties, indicating that the loss of ELF antioxidant activity with the anticatalase chromatography was not due to a nonspecific interaction of ELF antioxidants with the affinity column.

Consistent with the concept that catalase is the major ELF antioxidant macromolecule, was the observation that the minimum concentration of catalase (Sigma Chemical Co.) necessary to completely protect HFL- 1 cells against $8 \mathrm{mU} / \mathrm{ml}$ glucose oxidase was $60 \mathrm{mU} / \mathrm{ml}$ (data not shown), while the minimum amount of ELF necessary to protect HFL- 1 cells was $20 \mu \mathrm{l} / \mathrm{ml}$ (Fig. $2 A$ ), which corresponds to a catalase concentration of $76 \pm 12 \mathrm{mU} / \mathrm{ml}$.

Evaluation of the source of ELF catalase. Since catalase is predominantly an intracellular protein, the possible sources of ELF catalase include red blood cells, alveolar inflammatory cells, and lung parenchymal cells. Red blood cell origin of ELF catalase could be excluded since, although the ELF catalase concentration was $3.8 \pm 0.6 \mathrm{U} / \mathrm{ml}$, the activity concentration in red blood cells was $10 \pm 2 \mathrm{mU} / \mu \mathrm{g}$ hemoglobin $(\mathrm{Hb})$ and all ELF samples used in this study contained $<1 \mu \mathrm{g} / \mathrm{ml} \mathrm{Hb}$. 
Table I. Relative Anti- $\mathrm{H}_{2} \mathrm{O}_{2}$ Properties of Serum Proteins Present in Epithelial Lining Fluid of the Normal Respiratory Tract

\begin{tabular}{lcccc}
\hline Serum protein & D & $\begin{array}{c}\text { Concentration } \\
\text { in Serum }\end{array}$ & $\begin{array}{c}\text { Concentration } \\
\text { in ELF }\end{array}$ & $\begin{array}{c}\text { Concentration } \\
\text { providing 50\% } \\
\text { reduction of the } \\
\text { cytotoxicity index }\end{array}$ \\
\hline Albumin & 66,000 & $495 \pm 119$ & $64 \pm 2$ & $\begin{array}{c}\text { Not protective } \\
\text { at } 64 \mu \mathrm{M}\end{array}$ \\
IgG & 160,000 & $75 \pm 24$ & $5.7 \pm 1.2$ & $\begin{array}{c}\text { Not protective } \\
\text { at } 12 \mu \mathrm{M}\end{array}$ \\
Ceruloplasmin & 134,000 & $2.2 \pm 0.4$ & $<0.15$ & $1.6 \pm 0.3$ \\
$\alpha 1$-Antitrypsin & 52,000 & $36 \pm 7$ & $3.1 \pm 0.5$ & $8.2 \pm 1.8$ \\
\hline
\end{tabular}

* Increasing amounts of each protein were added to the cytotoxicity assay using a $\mathrm{H}_{2} \mathrm{O}_{2}$-generating system and ${ }^{51} \mathrm{Cr}$-labeled $\mathrm{HFL}-1$ cells as described in the legend to Fig. 1. Shown is the concentration of each protein necessary to give a $50 \%$ reduction in the cytotoxicity index.

To insure that ELF catalase was not artifactually derived from lung inflammatory cell lysis during bronchoscopy, ELF catalase activity was measured before and after aspiration of bronchoalveolar lavage cells and fluid through the bronchoscope. No significant increase in ELF catalase activity was observed resulting from aspiration through the bronchoscope (ELF catalase before, $3.2 \pm 0.7 \mathrm{U} / \mathrm{ml}$; after, $4.4 \pm 0.9 \mathrm{U} / \mathrm{ml}, P$ $>0.3$ ).

Evidence suggesting that ELF catalase activity may be derived from lung cells (parenchymal as well as lung inflamma- tory cells) was provided by two observations. First, the ratios of intracellular antioxidant enzyme activity in ELF to that in lung inflammatory cells were markedly different from enzyme to enzyme (Table II), suggesting that either lung inflammatory cells secrete certain antioxidant enzymes in a selective manner or cells other than lung inflammatory cells are also contributing to the antioxidant activity of ELF. Second, while studies of isozyme pattern of ELF catalase and lung inflammatory cell catalase from the same individual revealed similar patterns in $70 \%$ of those studied (for an example, see Fig. 6, Subject $A$ ) distinctly different patterns were observed in $30 \%$ of those studied (see Fig. 6, Subject $B$ ), strongly suggesting that, at least in these individuals, parenchymal cells as well as inflammatory cells contributed to the presence of catalase in the ELF.

\section{Discussion}

Parenchymal cells of the lower respiratory tract are potentially exposed to toxic oxidants in the extracellular milieu. The present study was designed to evaluate the hypothesis that there are macromolecules present in the ELF capable of providing an antioxidant screen against $\mathrm{H}_{2} \mathrm{O}_{2}$, an oxidant that directly, or through its metabolites, plays a central role in mediating parenchymal cell injury in the lung. The data demonstrate that the ELF of the normal human lower respiratory tract does contain such macromolecules and characterization of the anti- $\mathrm{H}_{2} \mathrm{O}_{2}$ properties of ELF revealed that most was attributable to the presence of catalase. Although the specific cellular origin of ELF catalase is not known, it is clear that this enzyme is capable of providing protection to lung parenchymal cells against extracellularly generated $\mathrm{H}_{2} \mathrm{O}_{2}$.
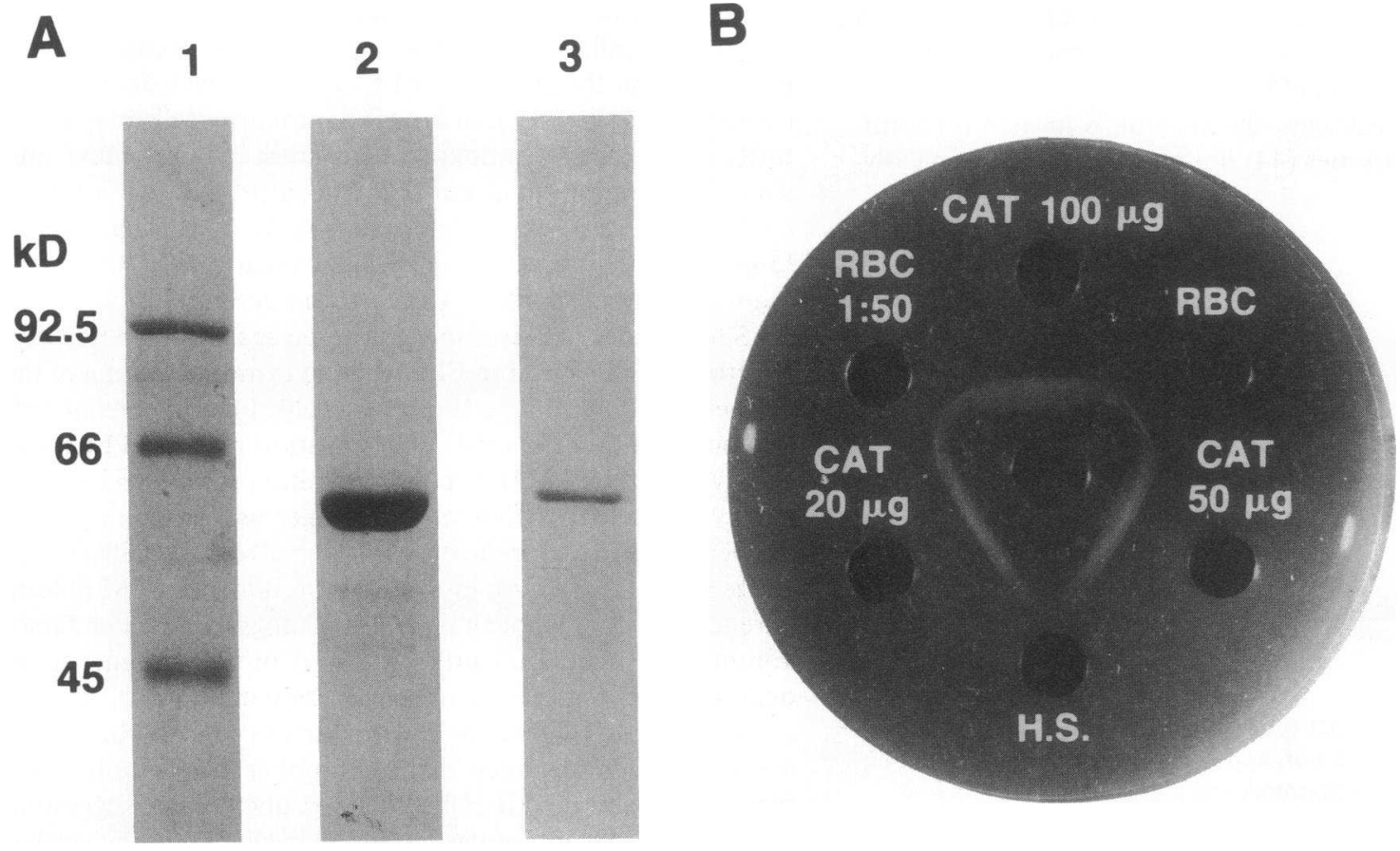

Figure 5. Characterization of the catalase antigen prepared from human red blood cell lysates and the anticatalase antiserum raised in sheep. $(A)$ Purified human red blood cell catalase was electrophoresed in a $7.5 \%$ polyacrylamide gel with SDS for $4 \mathrm{~h}$ at $60 \mathrm{~mA}$. Lane 1 , molecular weight markers, lane $2,100 \mu \mathrm{g}$ catalase; lane $3,20 \mu \mathrm{g}$ catalase. $(B)$ Ouchterlony analysis of sheep anti-human catalase antiserum. Center well contains $15 \mu \mathrm{l}$ anti-serum. Outer wells include: catalase, 100, 50, and $20 \mu \mathrm{g}(C A T 100 \mu \mathrm{g}, C A T 50 \mu \mathrm{g}$, and CAT $20 \mu \mathrm{g}$, respectively); red blood cell lysate undiluted and diluted 1:50 (RBC, RBC 1:50, respectively; and human serum (H.S.). 
Table II. Comparison of the Relative Proportions of Antioxidant Enzymes in ELF to that in Lung Inflammatory Cells

\begin{tabular}{lccr}
\hline \multicolumn{1}{c}{ Enzyme } & ELF & $\begin{array}{c}\text { Inflammatory } \\
\text { cells* }\end{array}$ & Ratio $^{*}$ \\
& $m U / \mu l$ & $m U / 10^{3}$ cells & \\
Catalase & $3.7 \pm 0.6$ & $2.1 \pm 0.6$ & 1.8 \\
Superoxide dismutase & $36.8 \pm 2.0$ & $4.2 \pm 1.4$ & 8.8 \\
Glutathionine peroxidase & $0.05 \pm 0.01$ & $0.11 \pm 0.05$ & 0.5 \\
Glutathionine reductase & $0.35 \pm 0.06$ & $0.03 \pm 0.01$ & 11.7
\end{tabular}

* Total cells recovered by bronchoalveolar lavage.

${ }^{\ddagger}$ Ratio of enzyme activity in ELF to that in inflammatory cells in (milliunits/microliter)/(milliunits $/ 10^{3}$ cells).

Possible sources of catalase in ELF. Catalase $\left(\mathrm{H}_{2} \mathrm{O}_{2}: \mathrm{H}_{2} \mathrm{O}_{2}\right.$ oxidoreductase; EC1.11.1.6), a 240,000-D enzyme present in virtually all mammalian cells $(13,37)$, uses $\mathrm{H}_{2} \mathrm{O}_{2}$ as a substrate in the catalytic conversion of $\mathrm{H}_{2} \mathrm{O}_{2}$ to $\mathrm{H}_{2} \mathrm{O}$ plus $\mathrm{O}_{2}$ and peroxidatic reactions. All catalases are thought to be oligomers composed of four, 60,000-D polypeptide chains held together mainly through hydrophobic interactions (37). Each chain is associated with a prosthetic group, protoporphyrin IX, located at the active site.

Catalase is synthesized by many cell types (38-44). In the lung, histochemical studies of the parenchyma from a variety of mammalian species have demonstrated that most of the catalase located in the lower respiratory tract is located within alveolar macrophages (44), type II alveolar epithelial cells, and Clara cells $(39,41-43)$. In these cells, catalase is found predominantly in peroxisomes, cytoplasmic organelles containing an array of $\mathrm{H}_{2} \mathrm{O}_{2}$-generating enzymes and catalase (38), but it also can be found in the cytoplasm (39), microperoxisomes (40), and phagolysosomes (45).

In alveolar macrophages, the enzyme is located predominantly within peroxisomes (44) but is also present in phagoly-
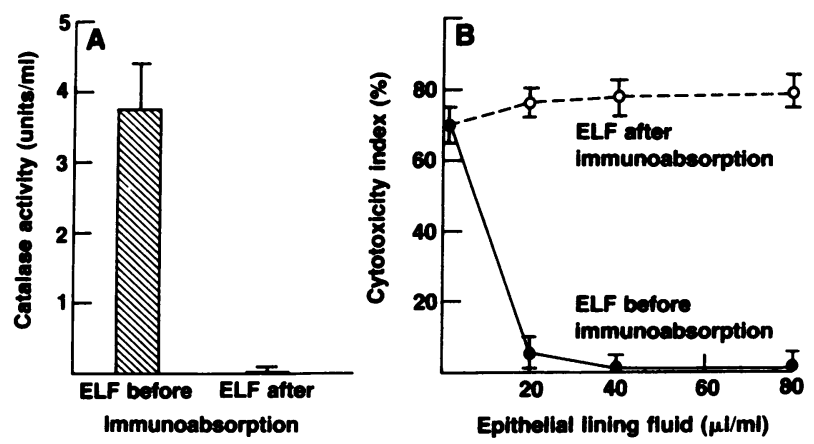

Figure 6. Demonstration that catalase is the major macromolecular antioxidant affording protection against $\mathrm{H}_{2} \mathrm{O}_{2}$ in the epithelial lining fluid $(E L F)$ of the lower respiratory tract. $(A)$ Catalase activity of ELF before and after passing through a cyanogen bromide-activated Sepharose 4-B affinity column to which antihuman catalase antibodies were bound. The anticatalase column completely removes catalase activity from the ELF. $(B)$ Antioxidant properties of ELF before $(\bullet)$ and after $(0)$ it had been depleted of catalase activity. Antioxidant activity was evaluated as a protection of HFL-1 cells against an $\mathrm{H}_{2} \mathrm{O}_{2}$-generating system as described in the legend to Fig. 1. sosomes (45). When macrophages are activated by a phagocytic stimulus, catalase is transferred from peroxisomes to phagolysosomes, thus increasing the phagolysosome catalase content 20-fold (45). Since lysosomal hydrolases are present in normal extracellular fluid of the lower respiratory tract (46), and since activated macrophages can markedly increase their release of lysosomal enzymes (47), it is possible that through this mechanism, alveolar macrophages contribute, at least in part, to the presence of catalase in normal ELF.

Importantly, several lines of evidence suggest that the presence of catalase in ELF is not an "artifact" of analysis originating from lysis of inflammatory lung cells such as alveolar macrophages during bronchoalveolar lavage or subsequent processing of the cells. First, Hook (46) has shown that alveolar macrophages obtained by lavage and maintained in suspension for several hours do not release lactate dehydrogenase or glutamic oxalacetic acid, indicating that the lavage procedure does not induce any irreversible injury to the recovered cells. The same study also demonstrated that centrifugation of alveolar macrophages up to $27,000 \mathrm{~g}$ for as long as $30 \mathrm{~min}$ did not result in the release of these cytoplasmic enzymes into the supernatant (46). Second, the present study indicated that repeated aspiration of lung inflammatory cells through the bronchoscope under conditions identical to those of the bronchoscopy, did not increase the catalase content of the supernatant. Third, whereas isoenzyme patterns of the catalase obtained from ELF and from lung inflammatory cells were identical in some individuals, the patterns were clearly different in others, suggesting that ELF catalase can originate from lung cells other than alveolar macrophages. However, these data are also consistent with the possibility that partial proteolytic degradation of ELF catalase may have contributed to the observed electrophoretic patterns.

While the different ratios of antioxidant enzymes in ELF to that in lung inflammatory cells argue against alveolar macrophage lysis as the source of ELF catalase, these data do not exclude the possibility that lung inflammatory cells may selectively secrete certain antioxidant enzymes. In this context, and since the variations in electrophoretic patterns of ELF catalase could conceivably represent partial proteolytic degradation, lung inflammatory cells, including alveolar macrophages, remain a potential source of ELF catalase activity.

Several lines of reasoning also argue against the possibility that the catalase found in ELF resulted from the trauma of the lavage procedure to type II or Clara cells. First, epithelial cells compose $<1 \%$ of the total cell population recovered by bronchoalveolar lavage (26). Second, the ratio of proteins in bronchoalveolar lavage to those in serum decreases as their molecular weights increase, indicating that the alveolar capillary barrier is intact (29). Third, morphometric studies by EM of lung parenchyma after whole lung lavage in dogs using much larger volumes of saline $(500 \mathrm{ml})$ than used in the present study, demonstrated that cell membranes remained intact without any evidence of cell lysis or destruction (48). Furthermore, the same study demonstrated that the number of intracellular lamellar bodies in type II cells remained unchanged, suggesting that intracellular molecules are not extruded from the epithelial lining cells by the lavage procedure. Finally, ELF catalase has been shown to be increased in the lower respiratory tract of smokers and patients with a variety of lung inflammatory disorders (49). Since the bronchoalveolar lavage procedure was identical for each group, the differences in ELF catalase con- 


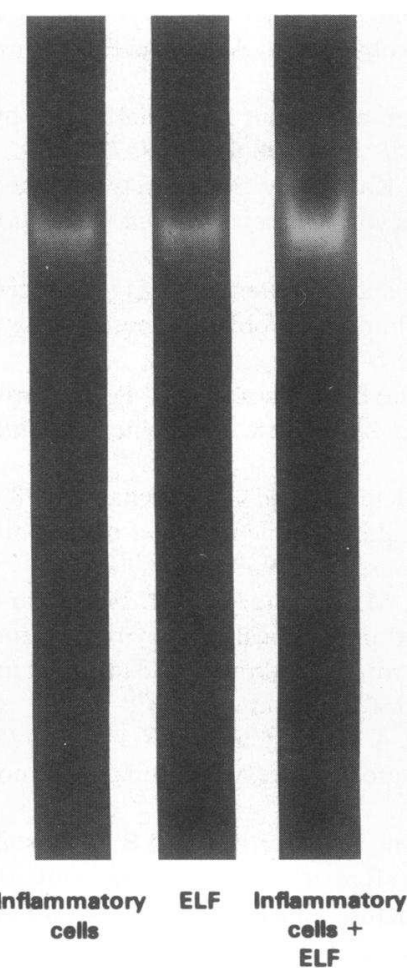

Subject A

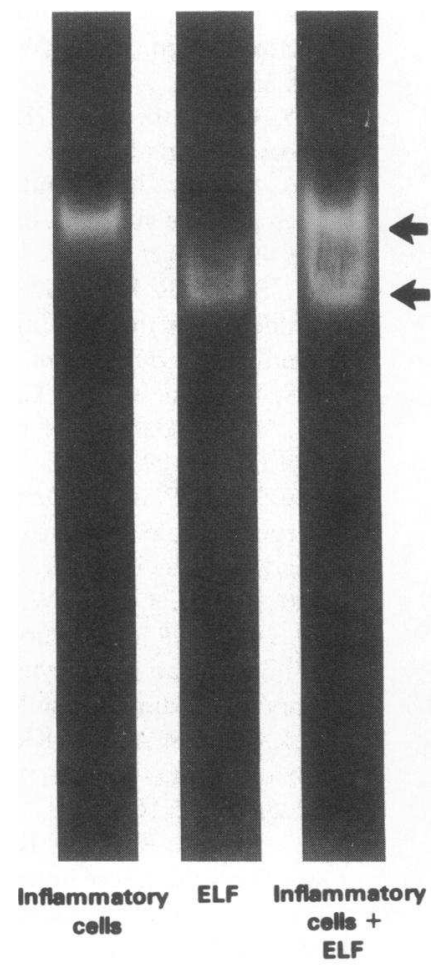

Subject B
Figure 7. Isoenzyme patterns of catalase from inflammatory cells and ELF obtained by bronchoalveolar lavage of normal individuals. Each sample, prepared in $150 \mathrm{mM} \mathrm{NaCl}$, was adjusted to have $1 \mathrm{U} / \mathrm{ml}$ catalase activity and was electrophoresed $(4 \mathrm{~h})$ into a $5 \%$ polyacrylamide slab gel (without SDS). The gel was subsequently washed in water, immersed in $1 \mathrm{mM} \mathrm{H}_{2} \mathrm{O}_{2}$ for $10 \mathrm{~min}$, rinsed in water, and stained with a solution of $30 \mathrm{mM}$ potassium ferricyanide and $37 \mathrm{mM}$ ferric chloride. Areas of the gel with $\mathrm{H}_{2} \mathrm{O}_{2}$-stained dark green while areas of catalase activity (i.e., absence of $\mathrm{H}_{2} \mathrm{O}_{2}$ ) remained clear. Catalase patterns from two subjects $(A$ and $B)$ are shown, including that for inflammatory cells alone, ELF alone, or inflammatory cells and ELF together. tent between the groups could not be due to lung parenchymal cell lysis induced by the bronchoalveolar lavage. The likely explanation is that catalase is present in ELF, either as a product of lung cell secretion or from an alternate source.

As alternatives to active secretion as a source of ELF catalase, it is possible that catalase reaches the ELF either by diffusion from plasma or through the processes of normal turnover of cells in the lower respiratory tract. Although normal serum contains low concentrations of catalase $(50,51)$, it is unlikely that serum catalase can contribute to that present in ELF since histochemical studies of lungs of animals injected intravenously with catalase demonstrated that the alveolar epithelial cell lining is relatively impermeable to this enzyme, probably because of its large molecular mass (52). A more likely source of ELF catalase is the turnover of catalase rich cells of the alveolar surface of the lung. In this regard, most enzymes present in normal serum are thought to originate from the processes of normal cell turnover $(53,54)$. Since alveolar macrophages, type II epithelial cells, and Clara cells all contain catalase and all of these cells are in contact with the epithelial surface of the lower respiratory tract, it is reasonable to hypothesize that the normal process of local cell turnover may contribute at least in part, to the accumulation of catalase in the extracellular milieu of the alveolar epithelial surface. In addition, since type II but not type I pneumocytes contain catalase particles (43), and since type I cells are most likely derived from type II cells (41), the process of differentiation of the type II cell may result in the release of catalase into ELF.

Antioxidant molecules other than catalase present in normal ELF. The present study demonstrates that among the macromolecules (defined operationally as those $>10 \mathrm{kD}$ ) with antioxidant properties against $\mathrm{H}_{2} \mathrm{O}_{2}$ present in ELF, catalase is the most important. However, other macromolecules with an- tioxidant properties are also present, including SOD, glutathione reductase, and peroxidase, and ceruloplasmin. The design of our study was such that we focused on anti- $\mathrm{H}_{2} \mathrm{O}_{2}$ defenses. However, that $\mathrm{SOD}$ is present may be relevant since, by virtue of the fact that it converts $\mathrm{O}_{2}^{-}$to $\mathrm{H}_{2} \mathrm{O}_{2}$, its role may be in preventing the ability of $\mathrm{O}_{2}^{-}$radical to reduce $\mathrm{Fe}^{3+}$ to $\mathrm{Fe}^{2+}$, (in conjunction with $\mathrm{H}_{2} \mathrm{O}_{2}$ ), which causes the formation of the toxic hydroxyl radical (55) or generation of a superoxide dependent neutrophil chemotactic factor (56).

Enzymes involved in the glutathione system, including the enzymes glutathione peroxidase and reductase, are also present in normal ELF. This is of interest in view of the high concentrations of GSH in ELF (57), suggesting that this glutathione system may play a role in the protection of the lower respiratory tract against toxic peroxides present in the extracellular milieu. However, the problems in concentrating glutathione, a low molecular weight species that is rapidly oxidized when removed from tissues (58) render this hypothesis difficult to verify. Nevertheless, since catalase is most efficient in scavenging high concentrations of $\mathrm{H}_{2} \mathrm{O}_{2}$, and the glutathione system functions efficiently at low $\mathrm{H}_{2} \mathrm{O}_{2}$ concentrations or with other peroxides (59), the two antioxidant systems would be complimentary.

The major extracellular antioxidant macromolecule in serum is ceruloplasmin (60), a 134-kD copper containing glycoprotein that catalyzes the oxidation of iron from $\mathrm{Fe}^{2+}$ to $\mathrm{Fe}^{3+}$, thus preventing iron from reacting with $\mathrm{H}_{2} \mathrm{O}_{2}$ to generate the toxic hydroxyl radical. While ceruloplasmin has been shown to prevent lipid peroxidation $(60,61)$, and was capable of protecting lung parenchymal cells against oxidant mediated injury in the present study, the concentrations present in ELF were too low to contribute to the observed antioxidant properties of ELF against $\mathrm{H}_{2} \mathrm{O}_{2}$. 
Because of the large dilution of ELF caused by the use of saline to perform the bronchoalveolar lavage, ELF molecules were concentrated by pressure filtration, and thus only molecules with a molecular mass $>10 \mathrm{kD}$ were analyzed. However, smaller antioxidant molecules such as vitamins $\mathrm{A}, \mathrm{C}$, and $\mathrm{E}$ are also present in biological fluids (62-65). Vitamin $A$ acts predominantly as a quencher of singlet oxygen (62), and vitamin $\mathrm{E}$ is thought to function mainly by interacting with lipid peroxy free radicals $\left(\mathrm{RO}_{2}\right)$ and stopping the cyclic chain reaction of lipid peroxidation $(63,65)$. Vitamin $C$ has recently been reported in high concentration in the extracellular fluid of the lower respiratory tract (64) with most of it in the reduced state. Furthermore, as mentioned above, reduced glutathione is present in high concentrations in ELF, adding further to the antioxidant defenses.

In the context of the above, it is reasonable to conclude that the ELF of the normal lower respiratory tract contains a wide array of antioxidant molecules. Among these, catalase seems to play a unique role by providing a mechanism whereby high concentrations of $\mathrm{H}_{2} \mathrm{O}_{2}$ can be metabolized thus preventing oxidant-mediated parenchymal cell injury. Since $\mathrm{H}_{2} \mathrm{O}_{2}$ plays a central role in mediating lung parenchymal cell injury, it is likely that the presence of catalase in ELF provides an important antioxidant screen to the lower respiratory tract.

\section{References}

1. Weibel, E. R. 1980. Design and structure of the human lung. In Pulmonary Diseases and Disorders. A. P. Fishman, editor. McGrawHill Book Co., New York. 224-271.

2. Frank, L., and D. Massaro. 1980. Oxygen toxicity. Am. J. Med. 69:117-126.

3. Huber, G. L., and D. B. Drath. 1981. Pulmonary oxygen toxicity. In Oxygen and Living Processes: An Interdisciplinary Approach. D. L. Gilbert, editor. Springer-Verlag, New York. 273-343.

4. McCord, J. M., and I. Fridovich. 1978. The biology and pathology of oxygen radicals. Ann. Int. Med. 89:122-127.

5. Mustafa, M. G., and D. F. Tierney. 1978. Biochemical and metabolic changes in the lung with oxygen, ozone, and nitrogen dioxide toxicity. Am. Rev. Respir. Dis. 118:1061-1085.

6. Pryor, W. A., K. Terauchi, and W. H. Davis, Jr. 1976. Electron spin resonance study of cigarette smoke by use of spin trapping techniques. Environ. Health Perspect. 16:161-175.

7. Klebanoff, S. J. 1980. Oxygen metabolism and the toxic properties of phagocytes. Ann. Int. Med. 93:480-489.

8. Hoidal, J. R., R. B. Fox, P. A. Le Marbe, R. Perri, and J. E. Repine. 1981. Altered oxidative metabolic responses in vitro of alveolar macrophages from asymptomatic cigarette smokers. Am. Rev. Respir. Dis. 123:85-89.

9. Greening, A. P., and D. B. Lowrie. 1983. Extracellular release of hydrogen peroxide by human alveolar macrophages: the relationship to cigarette smoking and lower respiratory tract infections. Clin. Sci. 65:661-664.

10. Davis, W., G. A. Fells, X. H. Sun, J. E. Gadek, A. Venet, and R. G. Crystal. 1984. Eosinophil-mediated injury to lung parenchymal cells and interstitial matrix. J. Clin. Invest. 74:269-278.

11. Martin, W. J., W. B. Davis, J. E. Gadek, B. A. Keogh, and R. G. Crystal. 1982. Alveolar macrophages from patients with idiopathic pulmonary fibrosis contributes to lung cell injury. Am. Rev. Respir. Dis. 125:91A. (Abstr.)

12. Fridovich, I. 1974. Superoxide dismutases. Adv. Immunol. 41:35-97.

13. Deisseroth, A., and A. L. Dounce. 1970. Catalase: physical and chemical properties, mechanisms of catalysis and physiological role. Physiol. Rev. 50:319-375.
14. Wendel, A. 1980. Glutathione peroxidase. In Enzymatic Basis of Detoxification. Vol. 1. W. B. Jakoby, editor. Academic Press, New York. 333-353.

15. Babior, B. M. 1978. Oxygen-dependent microbial killing by phagocytes. Parts I and II. N. Engl. J. Med. 298:659-668, 721-725.

16. Badwey, J. A., and M. L. Karnovsky. 1978. Active oxygen species and the function of phagocytic leukocytes. Annu. Rev. Biochem. 49:695-726.

17. Simon, R. H., C. H. Scoggin, and D. Patterson. 1981. Hydrogen peroxide canses the fatal injury to human fibroblasts exposed to oxygen radicals. J. Biol. Chem. 256:7181-7186.

18. Johnson, K. J., J. C. Fantone III, J. Kaplan, and P. A. Ward. 1981. In vivo damage of rat lungs by oxygen metabolites. J. Clin. Invest. 67:983-993.

19. Ward, P. A., G. O. Till, R. Kunkel, and C. Beauchamp. 1983. Evidence for role of hydroxyl radical in complement and neutrophildependent tissue injury. J. Clin. Invest. 72:789-801.

20. Repine, J. E., J. W. Eaton, M. W. Anders, J. R. Hoidal, and R. B. Fox. 1979. Generation of hydroxyl radical by enzymes, chemicals, and human phagocytes in vitro: detection with the anti-inflammatory agent, dimethyl sulfoxide. J. Clin. Invest. 64:1642-1651.

21. Clark, R. A., S. J. Klebanoff, A. B. Einstein, and A. Fefer. 1975. Peroxidase- $\mathrm{N}_{2} \mathrm{O}_{2}$-halide system: cytotoxic effect on mammalian tumor cells. Blood. 45:161-170.

22. Bradley, K. H., O. Kawanami, V. J. Ferrans, and R. G. Cystal. 1980. The fibroblast of human lung alveolar structures: a differentiated cell with a major role in lung structure and function. Methods Cell Biol. 21A:37-64.

23. Kniazeff, A. J., G. D. Stoner, L. Terry, R. M. Wagner, and R. D. Hoppenstand. 1976. Characterization of epithelial cells cultured from feline lung. Lab. Invest. 34:495-500.

24. Monboisse, J. C., P. Braquet, A. Randoux, and J. P. Borel. 1983. Non-enzymatic degradation of acid-soluble calf skin collagen by superoxide ion: protective effect of flavonoids. Biochem. Pharmacol. 32:53-58.

25. Pick, E., and Y. Keisari. 1981. Superoxide anion and hydrogen peroxide production by chemically elicited peritoneal macrophages. Induction by multiple morphologic stimuli. Cell Immunol. 59:301318.

26. Hunninghake, G. W., J. E. Gadek, O. Kawanami, V. J. Ferrans, and R. G. Crystal. 1979. Inflammatory and immune processes in the human lung in health and in disease: evaluation by bronchoalveolar lavage. Am. J. Pathol. 97:149-205.

27. Rennard, S. I., G. Basset, D. Lecossier, K. M. O’Donnell, P. G. Martin, and R. G. Crystal. 1986. Estimation of volume of epithelial lining fluid recovered by lavage using urea as marker of dilution. $J$. Appl. Physiol. 60:532-538.

28. Shelby, S. A., J. E. Paciga, and J. V. Balis. 1977. Purification of surfactant from lung washings and washings contaminated with blood constituents. Lipids. 12:505-510.

29. Bell, D. Y., J. A. Haseman, A. Spock, G. McLennan, and G. E. R. Hook. 1981. Plasma proteins of the bronchoalveolar surface of the lungs of smokers non-smokers. Am. Rev. Respir. Dis. 124:1229.

30. Aebi, H. 1984. Catalase in vitro. Methods Enzymol. 105:121126.

31. Bonaventura, J., W. A. Schroeder, and S. Fang. 1972. Human erythrocyte catalase: an improved method of isolation and a reevaluation of reported properties. Arch. Biochem. Biophys. 150:606-617.

32. Rutherford, R. T., and D. J. Weatherall. 1979. Deficient hemo-synthesis as the cause of noninducibility of hemoglobin synthesis in a friend erythroleukemia cell line. Cell. 16:415-423.

33. Crapo, J. D., J. M. McCord, and I. Fridovich. 1978. Preparation and assay of superoxide dismutases. Methods Enzymol. 53:382393.

34. Paglia, D. E., and W. M. Valentine. 1967. Studies on the quantitative and qualitative characterization of erythrocyte glutathione peroxidase. J. Lab. Clin. Med. 70:158-169. 
35. Horn, H. D. 1965. Glutathione reductase. In Methods of Enzymatic Analysis. H. V. Bergmeyer, editor. Academic Press, New York. 875-894.

36. Woodbury, W., A. K. Spencer, and M. A. Stahman. 1972. An improved procedure using ferricyanide for detecting catalase isozymes. Anal. Biochem. 44:301-305.

37. Schonbaum, G. R., and B. Chance. 1976. Catalase. In The Enzymes. Vol. XIII. P. D. Boyer, editor. Academic Press, New York. 363-408.

38. DeDuve, C., and P. Baudhuin. 1976. Peroxisomes (microbodies and related particles). Physiol. Rev. 46:323-357.

39. Goldenberg, H., M. Huttinger, V. Kollner, R. Kramer, and M. Pavelka. 1978. Catalase positive particles from pig lung. Biochemical preparations and morphological studies. Histochemistry. 56:253-264.

40. Novikoff, A. B., P. M. Novikoff, C. Davies, and N. Quintana. 1972. Studies on microperoxisomes. II. A cytochemical method for light and electron microscopy. J. Histochem. Cytochem. 20:10061023.

41. Moriguchi, K., N. Higashi, S. Kitagawa, K. Takase, N. Ohya, T. Uyeda, and K. I. Hirai. 1984. Differentiation of human pulmonary alveolar epithelial cells revealed by peroxisome changes in pulmonary proteinosis. Exp. Mol. Pathol. 40:262-270.

42. Schneeberger, E. E. 1972. A comparative cytochemical study of microbes (peroxisomes) in great alveolar cells of rodents, rabbit and monkey. J. Histochem. Cytochem. 20:280-291.

43. Petrick, P. 1971. Fine structural identification of peroxisomes in mouse and rat bronchial and alveolar epithelium. J. Histochem. Cytochem. 19:339-348.

44. Davies, P., D. B. Drath, E. E. Engel, and G. L. Huber. 1979. The localization of catalase in the pulmonary alveolar macrophage Lab. Invest. 40:221-226.

45. Stossel, T. P., R. J. Mason, T. D. Pollard, and M. Vaughan. 1972. Isolation and properties of phagocytic vesticles. II. Alveolar macrophages. J. Clin. Invest. 51:604-614.

46. Hook, G. E. R. 1978. Extracellular hydrolases. Biochemistry. 17:520-528.

47. Schnyder, J., and M. Bagglioni. 1978. Secretion of lysosomal hydrolases by stimulated and nonstimulated macrophages. J. Exp. Med. 135:435-450.

48. Huber, G. L., L. H. Edmunds, and T. M. Finley. 1971. Effects of experimental saline lavage in pulmonary mechanics and morphology. Am. Rev. Respir. Dis. 104:337-347.

49. Greening, A. P., I. Downing, N. E. Wood, and D. C. Flenley. 1985. Pulmonary anti-oxidants: catalase activity but not ceruloplasmin is increased in smokers. Am. Rev. Respir. Dis. 131:A385.

50. Smith, E. L., R. L. Hill, I. R. Lehman, R. L. Lefkowitz, P. Handler, and A. White. 1983. Body fluids and their constituents: blood. In Principles of Biochemistry: Mammalian Biochemistry. R. S. Laufer, E. Warren, D. McIvor, editors, McGraw-Hill Book Co., New
York. 3-37.

51. Fleisher, G. A., K. G. Wakim, M. Pankow, D. Osborne, L. Clapp, and E. VanHook. 1963. The fate of enzymes in body fluids: an experimental study. Disappearance rates of glutamic-pyruvic transaminase under various conditions. J. Clin. Med. 61:76-85.

52. Goth, L., H. Nemeth, and I. Meszaros. 1983. Serum catalase activity for detection of hemolytic diseases. Clin. Chem. 29:741-743.

53. Mitchess, R. A., E. L. Arcinue, J. C. Partin, J. S. Partin, M. L. Ram, C. H. Chang, J. Smialek, and A. Sarnaik. 1985. Quantitative evaluation of the extent of hepatic enzyme changes in Reye syndrome compared to normal liver or with non-Reye live disorders: objective criteria for animal models. Pediatr. Res. 19:19-22.

54. Schneeberger, E. E., and M. J. Karnovsky. 1971. The influence of intrascular fluid volume on the permeability of newborn and adult mouse lungs to ultrastructural protein tracers. J. Cell. Biol. 49:319223.

55. Fridovich, I. 1978. The biology of oxygen radicals. Science (Wash. DC). 201:875-879.

56. Petrone, W. F., D. K. English, K. Wong, and J. M. McCord. 1980. Free radical and inflammation: superoxide-dependent activation of a neutrophil chemotactic factor in plasma. Proc. Natl. Acad. Sci. USA. 70:1159-1163.

57. Cantin, A. M., S. L. North, R. C. Hubbard, and R. G. Crystal. 1987. Normal alveolar epithelial lining fluid contains high levels of glutathione. J. Appl. Physiol. 63:152-157.

58. Adams, J. D., B. H. Lanterbury, and J. R. Mitchell. 1983. Plasma glutathione and glutathione disulphide in the rat: regulation and response to oxidative stress. J. Pharmacol. Exp. Ther. 227:749754.

59. Chance, B., H. Sies, and A. Boveris. 1979. Hydroperoxide metabolism in mammalian organs. Physiol. Rev. 59:527-605.

60. Gutteridge, J. M. C., R. Richmond, and B. Halliwell. 1980. Oxygen free-radicals and lipid peroxidation: inhibitions by the protein ceruloplasmin. FEBS (Fed. Eur. Biochem. Soc.) Lett. 112:269-272.

61. Al-Timimi, D. J., and T. L. Dormandy. 1977. The inhibition of lipid autoxidation by human ceruloplasmin. Biochem. J. 168:283288.

62. Forman, H. J., and A. B. Fisher. 1982. Antioxidant defenses. In Oxygen and Living Processes. An Interdisciplinary Approach. D. L. Gilbert, editor. Springer-Verlag, New York. 235-249.

63. Witting, L. A. 1980. Vitamin E and lipid antioxidants in freeradical initiated reactions. In Free Radicals in Biology. Vol. IV. W. A. Pryor, editor, Springer-Verlag, New York. 295-319.

64. Skoza, L., A. Snyder, and Y. Kikkawa. 1983. Ascorbic acid in bronchoalveolar washings. Lung. 161:99-109.

65. Pacht, E. R., H. Kaseki, J. R. Mohammed, D. G. Cornwell, and W. B. Davis. 1986. Deficiency of Vitamin E in the alveolar fluid of cigarette smokers: influence on alveolar macrophage cytotoxicity. $J$. Clin. Invest. 77:789-796. 